\title{
Air sampling for detection of infectious laryngotracheitis (ILT) in commercial poultry flocks
}

Lauren Brown ${ }^{1,2}$, Dilhani Premaratna' ${ }^{1}$, Yonatan Segal ${ }^{3}$ and Travis Beddoe ${ }^{1,3^{*}}$ (D)

\begin{abstract}
Objective: Infectious laryngotracheitis (ILT) is an acute and highly contagious viral respiratory disease of poultry, caused by gallid herpesvirus 1 (ILTV), which causes significant economic losses. Due to recent outbreaks of ILT in Australia, it has been proposed that ILT could be transmitted between poultry sheds by airborne transmission; however, there has never been direct detection of ILTV from air samples. We aimed to optimize a sampling system for the detection of airborne ILTV in poultry sheds.

Results: Poultry farms with a known outbreaks of ILT were used for detection of airborne ILTV. Infected chickens were verified by detection of ILTV nucleic acid in feather shafts with all farms being positive. Using a liquid cyclonic impinging device, it was found that recovery and detection of airborne ILTV was possible in alkaline PEG buffer. Additional sampling was performed at different heights to determine the presence of ILTV in the air. In farm 3, all three air samples at both heights were positive for ILTV while at farm 2 only one sample at $45 \mathrm{~cm}$ was positive. We envisaged in the future air sampling will be able to detect and track potential transmission of ILTV both inside and outside of the poultry shed.
\end{abstract}

Keywords: Air sampling, ILT, PCR, Gallid herpesvirus 1, Poultry

\section{Introduction}

The causative agent of infectious laryngotracheitis (ILT) is gallid herpesvirus 1, a highly contiguous virus that is characterized by severe dyspnea, coughing, and rales [1]. ILT infection has a significant economic impact on the poultry industry across the world due to reduce egg production and large mortality rate (up to 70\%) [2]. Live attenuated vaccines, and biosecurity measures are currently the most effective control measures for ILT [2]. However, outbreaks of ILT occur regularly in Australia and recently, this resulted in novel strains due to recombination of the vaccine strains $[3,4]$.

\footnotetext{
${ }^{*}$ Correspondence: t.beddoe@latrobe.edu.au

${ }^{3}$ Department of Jobs, Precincts and Regions, Victorian Government,

Attwood, Melbourne, VIC, Australia

Full list of author information is available at the end of the article
}

Due to the substantial increase in the number of outbreaks of ILT in broiler farms in the Mornington Peninsula area of Victoria raised the concerns about the route of transmission of gallid herpesvirus 1. Potential sources of gallid herpesvirus 1 infection between poultry farms are infected chickens, contaminated litter, dust, drinking water, fomites and darkling beetles, which infect poultry through ocular and respiratory routes [2]. However, there were concerns that transmission between farms were occurring by being air. A single report suggests that airborne transmission is the likelihood of infection is ten times higher when within the vicinity of a clinically infected farm and within the vicinity of market gardens that apply raw poultry manure as fertiliser however, no direct testing of air was performed [5]. It has also been shown that relatively high levels of infectious gallid herpesvirus 1 are carried in dust which could 
result in increased airborne transmission [6]. Some other viral poultry diseases are transmitted by air, and thus it is a priority to determine if the wind also spreads gallid herpesvirus 1 . Here, we report a sampling system for the detection of airborne gallid herpesvirus 1 in commercial poultry sheds.

\section{Main text}

\section{Materials and methods}

\section{Farm identification, selection and definitions}

In this study, three case farms were selected throughout March and April of 2017 from a list of broiler farms located in the Mornington Peninsula region, Victoria. The flocks were comprised of mixed-sex of Cobb and Ross broiler breeds between 36-50 days of age. Upon the onset of an outbreak of ILT in a poultry farm based on clinical diagnosis, the company veterinarian or service person notified the investigators. As soon as ILT case farms had been identified, an investigator visited the farm and collected air samples within $24 \mathrm{~h}$.

\section{Air sampling procedure}

All air samples were collected using the SKC Biosampler ${ }^{\circledR}$; a liquid cyclonic impinging device (SKC Inc, USA) and BioLite pump (SKC Inc, USA) as shown in Fig. 1. Briefly, the collection vessel contained $5 \mathrm{ml}$ of alkaline polyethene glycol (PEG) solution $(60 \% \mathrm{v} / \mathrm{v}$ PEG 200 (Sigma-Aldrich, USA), 20 mM KOH, pH 13.5) or phosphate buffer saline (PBS) $\left(8.1 \mathrm{mM} \mathrm{Na}_{2} \mathrm{HPO}_{4}\right.$, $137 \mathrm{mM} \mathrm{NaCl}, 1.4 \mathrm{mM} \mathrm{KH}_{2} \mathrm{HPO}_{4}$ and $2.6 \mathrm{mM} \mathrm{KCl}$ ) in which material from the air was trapped. The air sampler was used for $20 \mathrm{~min}$ in three different locations within the shed at the height of either $45 \mathrm{~cm}$ or $120 \mathrm{~cm}$ off the floor at a rate of $12.5 \mathrm{~L}$ per min placed on card table. In between sampling, the glass collection vessel was disinfected with $80 \%$ ethanol. Each sample was transferred from the collection vessel to a clean sterile $15 \mathrm{ml}$ conical centrifuge tubes for transport and storage in the laboratory at $-20^{\circ} \mathrm{C}$.

\section{DNA extraction of feather samples}

Feather samples were gathered randomly off the floor inside the selected sampling shed. Feathers were collected and stored in $50 \mathrm{ml}$ conical centrifuge tubes and stored at $-20{ }^{\circ} \mathrm{C}$ until processing. Approximately $5 \mathrm{~mm}$ of each collected feather shaft was cut off and were divided into groups of three, with four shafts per group. Total DNA was extracted from feathers tips using the Mouse Direct PCR Kit (Biotool, USA) following the manufacturer's instructions.

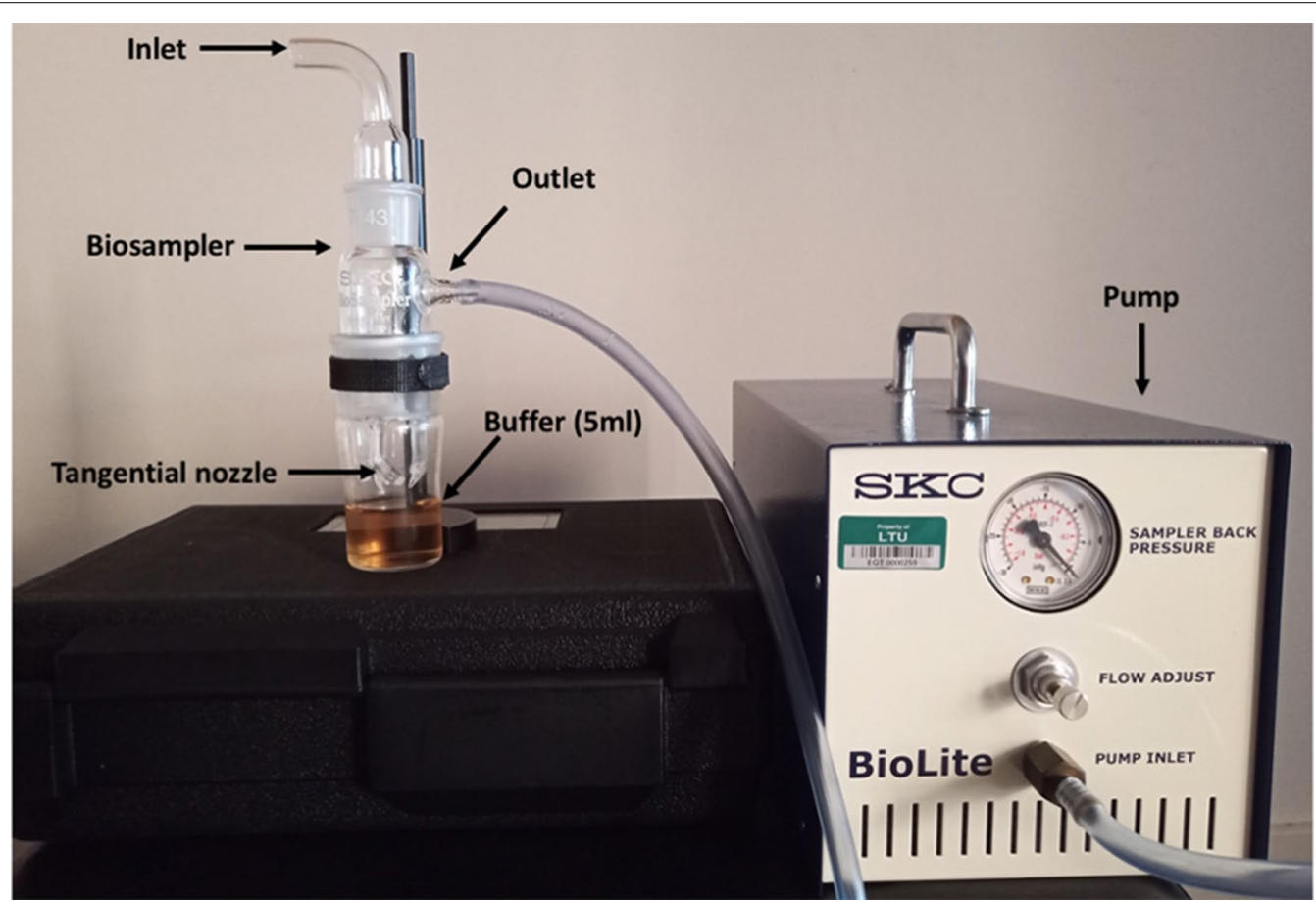

Fig. 1 SKC Biosampler experimental setup. The glass Biosampler was assembled with glass collection vessel containing $5 \mathrm{ml}$ of buffer in which the pump was attached to drive air through the collection buffer using the specialized tangential nozzle. The Biosampler were placed at different heights for the collection of airborne material 


\section{DNA purification of air and feather samples}

DNA purification from air and feather samples were performed as described by $\mathrm{Li}$ and Sheen with the following modifications [7]. Briefly, $500 \mu \mathrm{l}$ of DNA binding solution (6 M NaI) is added to $300 \mu \mathrm{l}$ of extracted DNA feather sample to which $10 \mu \mathrm{l}$ of $100 \mathrm{mg} / \mathrm{ml}$ silica dioxide (Sigma, USA) was added, vortexed then incubated at room temperature for $2 \mathrm{~min}$. Samples were centrifuged for $10 \mathrm{~s}$, and the supernatant removed. Silica matrix was then washed with $500 \mu \mathrm{l}$ of washing solution $(50 \% \mathrm{v} / \mathrm{v}$ ethanol, $10 \mathrm{mM}$ Tris- $\mathrm{HCl} \mathrm{pH} \mathrm{7.5,} 100 \mathrm{mM} \mathrm{NaCl}$ and $1 \mathrm{mM}$ ethylenediaminetetraacetic acid (EDTA), centrifuged at $13,000 \times g$, discarded supernatant and repeated once. Silica matrix was resuspended in $30 \mu \mathrm{l}$ of sterile water and incubated at $70{ }^{\circ} \mathrm{C}$ for $2 \mathrm{~min}$. The samples were centrifuged at 16,000xg for 2 min and eluted DNA transferred to a fresh tube and stored at $-20{ }^{\circ} \mathrm{C}$. A similar purification method was used for the air sample except the starting volume was $2.5 \mathrm{ml}$ to which $3 \mathrm{ml}$ of DNA binding solution and $100 \mu \mathrm{l}$ of $100 \mathrm{mg} / \mathrm{ml}$ silica dioxide (Sigma, USA) was added. DNA was eluted by the addition of 100 $\mu \mathrm{l}$ of sterile water.

\section{PCR for detection of Gallid herpesvirus 1}

Conventional PCR was used for the detection of gallid herpesvirus 1 by the presence of the thymidine kinase (TK) gene, as described by Mahmoudian et al. (2011), with the following modifications [8]. Reactions were carried out in a final volume of $25 \mu \mathrm{L}$ and amplified in a C-Master GT thermal cycler (Dynamica, Australia). The following amplification conditions consisted of an initial denaturation step of $94{ }^{\circ} \mathrm{C}$ for $3 \mathrm{~min}, 94{ }^{\circ} \mathrm{C}$ for $15 \mathrm{~s}, 60{ }^{\circ} \mathrm{C}$ for $45 \mathrm{~s}, 72^{\circ} \mathrm{C}$ for $150 \mathrm{~s}$, repeated for 35 times with a final extension at $72{ }^{\circ} \mathrm{C}$ for $3 \mathrm{~min}$. Amplicon size was checked by agarose electrophoresis migration by loading directly on $1 \%(\mathrm{w} / \mathrm{v})$ agarose (Lonza, USA) gel, prepared as per manufacturer's instructions, with the addition of $0.5 \mu \mathrm{L}$ of Sybr ${ }^{\circledR}$ Safe DNA Gel Stain (Life Technologies, USA). The gel was run at $110 \mathrm{~V}$ for $45 \mathrm{~min}$ and imaged using the GelDoc $^{\mathrm{TM}} \mathrm{XR}+$ (BioRad, USA) instrument and software.

\section{Results}

Air samples in farm 1 were initially collected using a PBS buffer; however, the presence of gallid herpesvirus 1 was not detected suggesting the possibility this buffer is unsuitable for collection of viral samples (Fig. 2) (Additional file 1). However, the use of alkaline PEG as a collection buffer in farms 2 and 3 allowed the detection of gallid herpesvirus 1 by amplification of the TK gene (2250 bp amplicon) on new farms (Fig. 2). Sampling occurred at two heights with all sample sites and heights in farm 3 being positive for gallid herpesvirus 1 while only one site in farm 2 at $45 \mathrm{~cm}$ off the floor was positive (Fig. 2). All farms that were sampled had reported outbreaks of ILT and thus to confirm the presence of ILTV infected chickens on farms; a non-invasive method was used [9]. Feathers were collected off the ground and DNA extracted from shafts. The presence of gallid herpesvirus 1 was seen at all farms with Farm 3 showing the highest level of infection (Fig. 3) (Additional file 1).

\section{Discussion}

We have developed a sampling system for the detection of airborne gallid herpesvirus 1 by PCR. The initial use of PBS buffer to collect airborne material was unsuccessful which was a surprise as has been used in the past as a collection media in the successful isolation of airborne Porcine Reproductive and Respiratory Syndrome Virus (PRRSV) and influenza H1N1 $[10,11]$. However, this was done in conjunction with other solutions such as ethylene glycol, bovine serum albumin (BSA) and activated charcoal [11]. The use of alkaline PEG solution as sample buffer was successful in detecting the presence of gallid herpesvirus 1 which may be

\begin{tabular}{|c|c|c|c|c|c|c|c|c|c|c|c|c|c|c|c|c|c|}
\hline & \multicolumn{3}{|c|}{ Farm 1} & \multicolumn{6}{|c|}{ Farm 2} & \multicolumn{6}{|c|}{ Farm 3} & & \\
\hline buffer & \multicolumn{3}{|c|}{ PBS } & \multicolumn{6}{|c|}{ PEG } & \multicolumn{6}{|c|}{ PEG } & & \\
\hline height & \multicolumn{3}{|c|}{$45 \mathrm{~cm}$} & \multicolumn{3}{|c|}{$45 \mathrm{~cm}$} & \multicolumn{3}{|c|}{$120 \mathrm{~cm}$} & \multicolumn{3}{|c|}{$45 \mathrm{~cm}$} & \multicolumn{3}{|c|}{$120 \mathrm{~cm}$} & \multicolumn{2}{|c|}{ Control } \\
\hline sample & 1 & 2 & 3 & 1 & 2 & 3 & 1 & 2 & 3 & 1 & 2 & 3 & 1 & 2 & 3 & + & - \\
\hline $\begin{array}{l}000 \mathrm{bp} \longrightarrow \\
500 \mathrm{bp} \longrightarrow \\
000 \mathrm{bp} \longrightarrow \\
500 \mathrm{bp} \longrightarrow\end{array}$ & & & & & $\rightarrow$ & & & & & 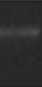 & - & - & $\rightarrow$ & 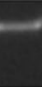 & & & \\
\hline
\end{tabular}

Fig. 2 Identification of gallid herpesvirus 1 from air samples by PCR. Air samples collected from various farms at different heights and buffers were analyzed for the presence of gallid herpesvirus 1 by PCR. The amplified product was analyzed on a $1 \%(\mathrm{w} / \mathrm{v})$ agarose gel. A single band is shown that corresponds to predicted amplicon containing the TK gene (2250 bp). The purified gallid herpesvirus 1 DNA from infected tissue was used as a positive control $(+)$ template, and no amplification was seen in the negative $(-)$, no template, control 


\begin{tabular}{|c|c|c|c|c|c|c|c|c|c|c|c|}
\cline { 2 - 9 } \multicolumn{1}{c|}{} & \multicolumn{3}{c|}{ Farm 1 } & \multicolumn{3}{c|}{ Farm 2 } & \multicolumn{3}{c|}{ Farm 3 } & \multicolumn{2}{c|}{ Control } \\
\hline sample & 1 & 2 & 3 & 1 & 2 & 3 & 1 & 2 & 3 & + & - \\
\hline $3000 \mathrm{bp} \longrightarrow$ \\
$2500 \mathrm{bp} \longrightarrow$ \\
$2000 \mathrm{bp} \longrightarrow$ \\
$1500 \mathrm{bp} \longrightarrow$
\end{tabular}

Fig. 3 Identification of gallid herpesvirus 1 from feather shafts by PCR. Pools of feathers $(n=4)$ per sample were collected randomly from the floor of the poultry shed and presence of gallid herpesvirus 1 was determined by PCR. A single band is shown that corresponds to predicted amplicon containing the TK gene (2250 bp). The purified gallid herpesvirus 1 DNA from infected tissue was used as a positive control (+) template, and no amplification was seen in the negative (-), no template, control

due to the fact this solution causes lysis of majority of microbes and inhibition of enzymes due to high $\mathrm{pH}$ which would preserve nucleic acid [12]. However, the use of this buffer excludes testing whether the detected nucleic acid was infectious. On farm 3 both measured heights $45 \mathrm{~cm}$ and $120 \mathrm{~cm}$ recorded positive samples in comparison with farm 2, which only had one positive sample at $45 \mathrm{~cm}$ high. This is approximately the same level as a chicken's mouth. It has been shown that relative humidity $(\mathrm{RH})$ can affect the airborne transmission of influenza virus, as demonstrated in the guinea pig model with deficient transmission at midrange and very high $\mathrm{RH}$ [13]. Ideally the $\mathrm{RH}$ should be between 50 and $70 \%$ in poultry shed (https://www. poultryventilation.com/node/4925) however the RH in each shed at farms 2 and 3 was not directly measured it was observed that on day of collection farm 2 had high humidity (>70\%). In contrast, on farm 3 it had low humidity $(<50 \%)$ suggesting that the humidity could be another factor that affects the transmission of gallid herpesvirus 1 by air.

To confirm the presence of gallid herpesvirus 1 on farms, feather shafts were used as a source of our DNA. This method is particularly beneficial as they are easy to collect, non-lethal for the bird, therefore useful for monitoring purposes. The majority of feather samples were positive for the presence of gallid herpesvirus 1 , except for one sample in farm 2 . On farm 2 it appears to have a low level of infection which may be why only one of the air samples from this farm returned a positive result.

In the future, this method will allow us to investigate whether transmission of ILT between poultry farms could occur via the air. In addition, these results will enable greater insight into the use of air sampling for the detection of other poultry viral diseases. This information will help in the deployment of air sampling and feather collection as means for a non-invasive biosecurity surveillance for the poultry industry.

\section{Limitations}

There are several limitations of this current study. (1) The current use of alkaline PEG does not allow for isolation and viability testing of the collected virus; thus use of PBS is required. Further work is required to develop a collection buffer to allow isolation and viability testing of gallid herpesvirus 1. (2) It appears humidity can play a role in the ability of gallid herpesvirus 1 to be airborne and direct measurements of humidity in sheds are required. (3) There were no molecular tests performed to distinguish the collected gallid herpesvirus 1 virus from vaccine strains and field isolates in this study. (4) The need to use quantitative PCR (qPCR) to measure v.

\section{Supplementary Information}

The online version contains supplementary material available at https://doi. org/10.1186/s13104-020-05399-2.

Additional file 1: The raw electrophoresis results for the identification of gallid herpesvirus 1 by PCR from collected air samples.

\section{Abbreviations}

ILT: Infectious laryngotracheitis; ILTV: Gallid herpesvirus 1; PCR: Polymerase chain reaction; PEG: Polyethene glycol; PBS: Phosphate buffer saline; DNA: Deoxyribonucleic acid; EDTA: Ethylenediaminetetraacetic acid; TK: Thymidine kinase; PRRSV: Porcine Reproductive and Respiratory Syndrome Virus; RH: Relative humidity.

\section{Acknowledgements}

We would like to thank the participating poultry owners for their time and assistance during sample collection.

\section{Authors' contributions}

LB and DP were responsible for the experimental work, data analysis, and writing of the manuscript. YS and TB coordinated the project, contributed to the experimental design, and reviewed the drafts. All authors read and approved the final manuscript.

\section{Funding}

Funding was granted for this project from Rural Industries Research and Development Corporation (RIRDC) and La Trobe University RFA industry collaboration grant. The funders had no role in the study design, data collection and analysis, decision to publish, or preparation of the manuscript. 
Availability of data and materials

The information supporting the conclusions of this article is included in the article.

\section{Ethics approval and consent to participate}

Not applicable.

\section{Consent for publication}

Not applicable.

\section{Competing interests}

The author(s) declared no potential conflicts of interest with respect to the research, authorship, and/or publication of this article.

\section{Author details}

${ }^{1}$ Department of Animal, Plant and Soil Science and Centre for AgriBioscience (AgriBio), La Trobe University, Bundoora, Melbourne, VIC, Australia. ${ }^{2}$ Center for Livestock Interactions With Pathogens (CLiP), La Trobe University, Bundoora, Melbourne, VIC, Australia. ${ }^{3}$ Department of Jobs, Precincts and Regions, Victorian Government, Attwood, Melbourne, VIC, Australia.

Received: 25 May 2020 Accepted: 27 November 2020

Published online: 09 December 2020

\section{References}

1. Fuchs W, Veits J, Helferich D, Granzow H, Teifke JP, Mettenleiter TC. Molecular biology of avian infectious laryngotracheitis virus. Vet Res. 2007;38(2):261-79.

2. Ou SC, Giambrone JJ. Infectious laryngotracheitis virus in chickens. World J Virol. 2012;1(5):142-9.

3. Blacker HP, Kirkpatrick NC, Rubite A, O'Rourke D, Noormohammadi AH. Epidemiology of recent outbreaks of infectious laryngotracheitis in poultry in Australia. Aust Vet J. 2011:89(3):89-94

4. Lee SW, Markham PF, Coppo MJ, Legione AR, Markham JF, Noormohammadi AH, Browning GF, Ficorilli N, Hartley CA, Devlin JM. Attenuated vaccines can recombine to form virulent field viruses. Science. 2012;337(6091):188
5. Johnson YJ, Gedamu N, Colby MM, Myint MS, Steele SE, Salem M. NL T: wind-Borne Transmission of Infectious Laryngotracheitis Between Commercial Poultry Operations. Int J Poultry Sci. 2005;4:263-7.

6. Roy P, Fakhrul Islam AFM, Burgess SK, Hunt PW, McNally J, Walkden-Brown SW. Real-time PCR quantification of infectious laryngotracheitis virus in chicken tissues, faeces, isolator-dust and bedding material over 28 days following infection reveals high levels in faeces and dust. J Gen Virol. 2015;96(11):3338-47.

7. Li JF, Sheen J. DNA purification from multiple sources in plant research with homemade silica resins. Methods Mol Biol. 2012;862:53-9.

8. Mahmoudian A, Kirkpatrick NC, Coppo M, Lee SW, Devlin JM, Markham PF, Browning GF, Noormohammadi AH. Development of a SYBR Green quantitative polymerase chain reaction assay for rapid detection and quantification of infectious laryngotracheitis virus. Avian Pathol. 2011;40(3):237-42.

9. Davidson I, Raibshtein I, Altori A, Elkin N. Infectious laryngotracheitis virus (ILTV) vaccine intake evaluation by detection of virus amplification in feather pulps of vaccinated chickens. Vaccine. 2016;34(13):1630-3.

10. Fabian P, McDevitt JJ, Houseman EA, Milton DK. Airborne influenza virus detection with four aerosol samplers using molecular and infectivity assays: considerations for a new infectious virus aerosol sampler. Indoor Air. 2009;19(5):433-41.

11. Hermann JR, Hoff SJ, Yoon KJ, Burkhardt AC, Evans RB. Zimmerman JJOptimizationon of a sampling system for recovery and detection of airborne porcine reproductive and respiratory syndrome virus and swine influenza virus. Appl Environ Microbiol. 2006;72(7):4811-8.

12. Chomczynski P, Rymaszewski M: Alkaline polyethylene glycol-based method for direct PCR from bacteria, eukaryotic tissue samples, and whole blood. Biotechniques 2006, 40(4):454, 456, 458.

13. Lowen AC, Mubareka S, Steel J, Palese P. Influenza virus transmission is dependent on relative humidity and temperature. PLoS Pathog. 2007;3(10):1470-6.

\section{Publisher's Note}

Springer Nature remains neutral with regard to jurisdictional claims in published maps and institutional affiliations.
Ready to submit your research? Choose BMC and benefit from:

- fast, convenient online submission

- thorough peer review by experienced researchers in your field

- rapid publication on acceptance

- support for research data, including large and complex data types

- gold Open Access which fosters wider collaboration and increased citations

- maximum visibility for your research: over 100M website views per year

At BMC, research is always in progress.

Learn more biomedcentral.com/submissions 